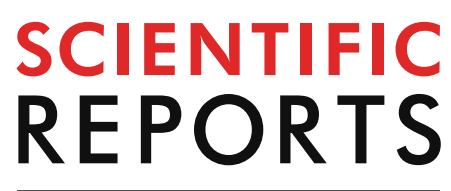

natureresearch

Check for updates

\title{
Survival and regeneration ability
} of clonal common milkweed \section{(Asclepias syriaca L.) after a single herbicide treatment in natural open sand grasslands}

\begin{abstract}
László Bakacsy ${ }^{\varpi}$ \& István Bagi
Invasive species are a major threat to biodiversity, human health, and economies worldwide. Clonal growth is a common ability of most invasive plants. The clonal common milkweed Asclepias syriaca $\mathrm{L}$. is the most widespread invasive species in Pannonic sand grasslands. Despite of being an invader in disturbed semi-natural vegetation, this plant prefers agricultural fields or plantations. Herbicide treatment could be one of the most cost-effective and efficient methods for controlling the extended stands of milkweed in both agricultural and protected areas. The invasion of milkweed stand was monitored from 2011 to 2017 in a strictly protected UNESCO biosphere reserve in Hungary, and a single herbicide treatment was applied in May 2014. This single treatment was successful only in a short-term but not in a long-term period, as the number of milkweed shoots decreased following herbicide treatment. The herbicide translocation by rhizomatic roots induced the damage of dormant bud banks. The surviving buds developing shoots, growth of the milkweed stand showed a slow regeneration for a longer-term period. We concluded that the successful control of milkweed after herbicide treatment depends on repeated management of treated areas to suppress further spreading during subsequent seasons.
\end{abstract}

Currently, invasive species are a major threat to biodiversity, human health, and economies ${ }^{1-4}$. It has been estimated that the fight against invasive species and the damage caused by them in European Union accounts for a minimum of 9.6-12.7 billion euros annually, and this amount is expected to rise to 20 billion euros annually $y^{1,5-7}$. The most important elements of protection against invasive species are prevention of introduction and early detection. In the case of established invasive species, the most successful options are eradication or isolation ${ }^{8-13}$. Herbicide treatment is one of the most effective ways to control or eradicate invasive plants in large areas ${ }^{10,14-19}$. Nevertheless, herbicide application of invasive species are rather arguable as their application negatively influence the growth of native species, composition of the species and abiotic factors (quality of the above and below ground water supply, soil and air) in protected areas ${ }^{18,20,21}$. Consequently, herbicides have to be carefully chosen (dosage, types and combination) based on the native species community ${ }^{16,19,20}$. Therefore, the herbicide application must be well planned and localized, the applied chemicals should be safe and effective. However, the use of these products in non-agricultural areas are very rarely accessible ${ }^{10,22,23}$. This knowledge gap also requires not only extensive research but also effective exchange of information and experience ${ }^{10,18,19}$.

Clonality is common among invasive plants ${ }^{24-26}$. The common reed Phragmites australis ${ }^{27}$, alligator weed Alternanthera philoxeroides ${ }^{28-30}$, Japanese knotweed Fallopia japonica ${ }^{31-35}$, Solidago species ${ }^{14,36}$, and Canada thistle Cirsium arvens $e^{37,38}$ are examples of problematic invasive clonal species. Their success is partly due to translocation of water, nutrients, and photoassimilates among physically interconnected shoots ${ }^{39-44}$. However, pathogens can also be transported through the same clonal network ${ }^{38,45-47}$ as can heavy metals ${ }^{48,49}$ and herbicides ${ }^{17,50-53}$. Bud banks on a clonal network play an important role in competition, vegetative multiplication, and resprouting ${ }^{54,55}$. An extensive dormant bud bank can be activated, resprouted, and made able to colonize an empty niche or 
re-establish monospecific stands after disturbance. Subsequently, the succession of natural vegetation can be impeded or completely obstructed. The mortality risk of clonal plants is low because death only occurs when both shoots and bud banks are simultaneously destroyed ${ }^{40,56-62}$. This possibly explains why management of clonal spreading species is difficult even with herbicide treatment ${ }^{63}$, and knowledge of invasive plant biology is essential for effective management ${ }^{8}$. While most studies involved a single year of monitoring, examination of herbicide treatment for several years before, during, and after treatment can provide useful information that will help guide management programs ${ }^{18,64-67}$.

Common milkweed Asclepias syriaca is one of the most dangerous invasive transformer species currently widespread in Hungary and is spreading in Czech Republic, Romania, Poland, Serbia, and several other countries $^{68-72}$. It primarily endangers psammophilous habitats where its structure differs from that of natural vegetation $^{73}$. It prefers mostly less heavy soils (well-drained sandy or sandy-loess soils). The colonization of A. syriaca can be facilitated by some anthropogenic disturbance of the soils ${ }^{69}$. The problems arising from the invasion of milkweed were primarily attributed to the assumption that it can inhibit the regeneration of natural vegetation $^{20,69,73,74}$. Despite the harmful effects of $A$. syriaca, it was only recently added to the list of Invasive Alien Species of Union Concern ${ }^{75}$. Milkweed originated in North America but is reportedly established in Continental, Mediterranean, and Pannonian Europe ${ }^{68}$. It is a perennial clonal plant ${ }^{68,69,76,77}$, and even though its shoots die back every autumn, it can resprout in the same place for extended periods ${ }^{69}$. The clonal structure of $A$. syriaca comprises solitary or few (2-5) groups of shoots that develop vegetatively by buds of plagiotropic rhizomatic roots ${ }^{69}$. To adequately control common milkweed, the bud banks of its roots and lateral roots must be eliminated. Control or eradication is an increasingly important action from both agricultural and conservation perspectives ${ }^{20,69,78-80}$. Complicating matters is the fact that extermination itself can create suitable conditions for colonization (e.g., soil disturbance), and large areas can become permanently milkweed-free only with coordinated efforts and at enormous $\operatorname{costs}^{69}$. Nevertheless, herbicide treatment may be a cost-effective method to control extended stands of milkweed in strictly protected areas ${ }^{10,20,68,69}$. The most frequently used herbicides for $A$. syriaca management are glyphosate and triclopyr, whereas fluroxypyr or dicamba are rarely used. These are often used individually or in combination with each other or with some level of mechanical control ${ }^{10,20,78,79,81}$. Relatively little information is available on the mid-term or long-term effects of post-emergent herbicides on A. syriaca. Here we report one of the first and longest monitoring periods of one-time herbicide treatment on a common milkweed stand and analyzed the before, after and during treatment effects. The basic hypothesis of the study is that clonality is an important factor for resistance to herbicide treatment. However, we assumed that a single herbicide treatment influences not only the further spread but also the vegetative and generative propagation of the invasive clonal plant. Therefore, we surveyed the complete shoot network of an isolated common milkweed stand in a long term period. We proposed the following questions: (a) How does the single treatment modify the number of shoots, shoot clusters, and reproductive characters (such as pods and pod-bearing) of common milkweed in the mid-term (three years after application)? (b) How does the stand density change after the single herbicide treatment? Which strategies are used by this invasive species to recover as the stand creates a denser or sparser shoot-network due to re-establish the original area? Based on these results it could be determined how the stand is able to survive the herbicide application. Furthermore, could be determined whether a single herbicide treatment is a successful control measure in the short and mid-term.

\section{Materials and methods}

Study site. The study site is in the UNESCO biosphere reserve, Fülöpháza Sand Dunes in the Kiskunság National Park, Central Hungary (Fig. 1). According to the European Union Habitat Directive (92/43/CEE), Pannonic or open sand steppes (Natura 2000 code: 6,260) represent prominent biomes ${ }^{82}$. Although these dry, nutrient-poor, calcareous sand habitats support only a few communities, many rare, endangered, and endemic species can be found in this area. The site has the following abiotic characteristics: groundwater level is at a high $\mathrm{depth}^{83,84}$, mean annual precipitation is $530-565 \mathrm{~mm}^{85-87}$, and mean annual temperature is $10.3^{\circ} \mathrm{C}^{87}$. As a result, vegetation grows in a mosaic pattern. The 2000-ha study area has been protected from grazing since 1974 . In the last quarter-century, the site has been invaded by common milkweed whose extended stands can be found throughout the protected area ${ }^{20,69,72,73}$. In 2011, an isolated milkweed stand embedded in natural psammophilous vegetation units was mapped (GPS coordinates: $\mathrm{N}^{\circ} 6^{\circ} 53.488^{\prime} \mathrm{E} 019^{\circ} 24.771^{\prime}$ ). It had a manageable number of shoots, pods, and stand size (approximately 400 shoots, with a maximum extension of $1,000 \mathrm{~m}^{2}$ ) and was separated from other clones (Fig. 1).

Herbicide treatment. Herbicide treatment of common milkweed was conducted in the framework of a KEOP tender (KEOP-7.3.1.2-09-2010-0024). The Environment and Energy Operational Program (KEOP) was carried out by the Kiskunság National Park Directorate with the support of the European Union and co-financing from the European Regional Development Fund. This program aimed to suppress the invasive alien plants in the most valuable sand areas of the Danube-Tisza Interfluve. Based on the existing Hungarian practical experiences two methods were applied for the treatment of the target vegetation in the study site: machine broadcast or motor sprayer was applied in buffer areas (formerly arable areas where the target vegetation was very dense), while lubrication (manually) was applied in the more valuable areas (natural vegetations). In the latter case, it can be minimalized the active ingredient to reach the non-target vegetation. The optimal application time was when the target vegetation reached the height of 20-40 cm, until it bloomed (from May to June 2014) ) $^{10,88}$. Moreover, the study site is rather big and there are some hard-accessible parts. Whereas the examined stand embedded in natural vegetation the lubrication was the applied technology. In this case, the used herbicide was Medallon, within a $50 \%$ aqueous solution $\left(2 \mathrm{lha}^{-1}\right)$. Glyphosate was the active ingredient in Medallon (it is an EPSG synthase inhibitor). Glyphosate belongs to category $\mathrm{G}$ of the Herbicide Resistance Action Committee 


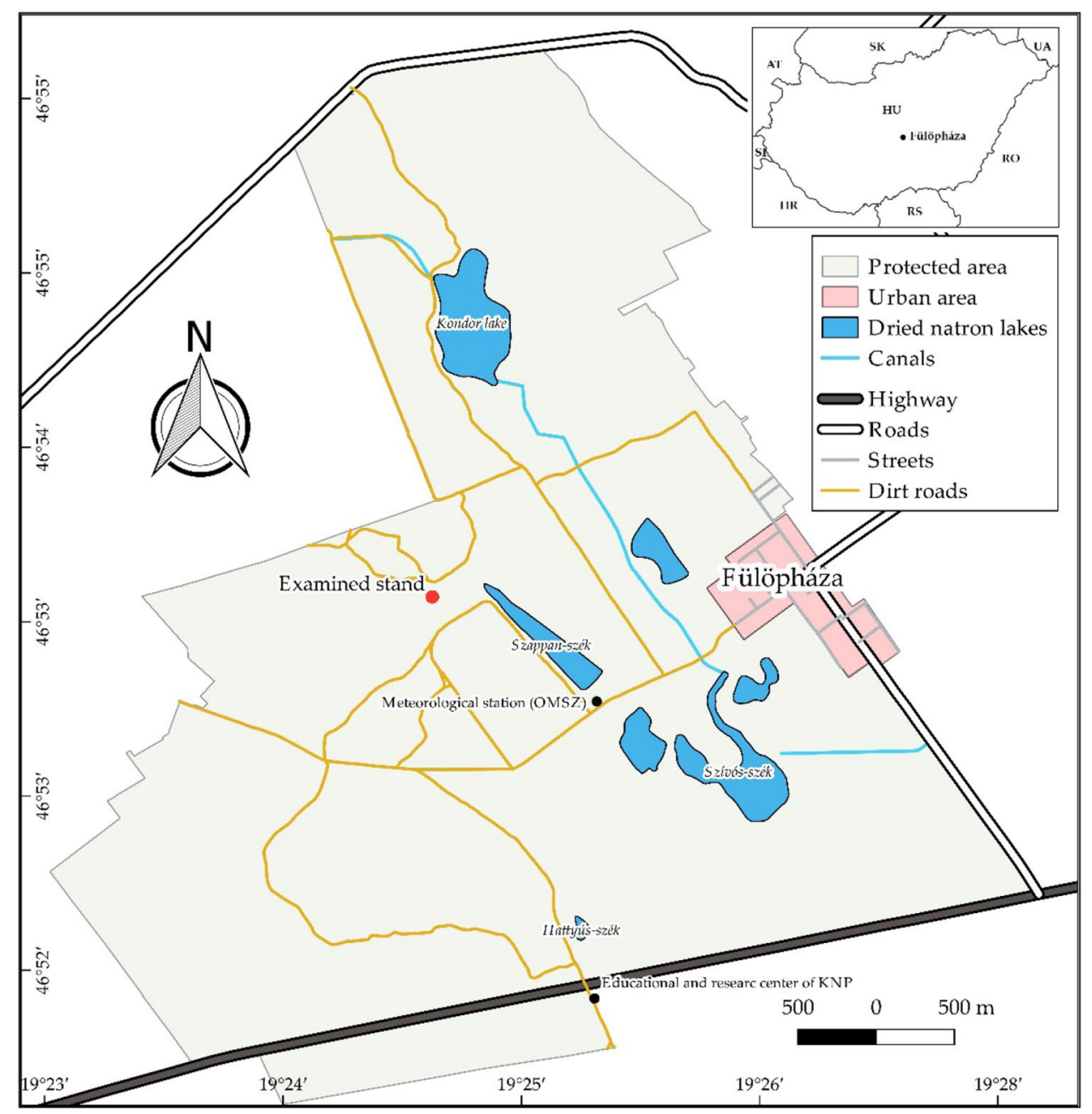

Figure 1. Location of the milkweed stand (red dot). The inserted image in the upper right corner shows the special protected Fülöpháza Sand Dunes, which are a part of Kiskunság National Park in Central Hungary.

and category 9 of the Weed Science Society of America. The examined stand was treated by herbicide only once (in May 2014) over the 7-year study period (the treatment was not repeated at all). The time of the treatment (phenology) and the used chemical was suitable for a recent study of a basic model for the control of invasive clonal plants ${ }^{34}$.

Monitoring of herbicide effectiveness for milkweed stand. The investigation extended to the whole stand, and the entire occupied area of the stand was covered with $2 \mathrm{~m} \times 2 \mathrm{~m}$ quadrats, in which the localization of the shoots, the number of solitary shoots and clusters (maximum distance between shoots of $15 \mathrm{~cm}$ ), and pod production of shoots were recorded. The positions of the shoots (to an accuracy of $5 \mathrm{~cm}$ ) were necessary to depict the pattern of the stand; this allowed the monitoring of individual shoots. The precise location of the shoots was used to calculate a heat map (or Kernel density) to determine the shoot density interpolated over the whole stand. Pod production served as a measure of vitality. The sampling was repeated for 7 years (from 2011 to 2017) in every July. The investigation period was divided as follows: before (the first 3 years), during (hereafter year of treatment, 2014), and after (the last 3 years) treatment.

Data processing. We used simple data processing methods and basic descriptive statistics to follow the fate of shoots in the stand and demonstrate the efficiency of the herbicide treatment. In this study, deeper statistical analysis (e.g. One-Way ANOVA) was not applicable because it would lead to misleading results due to pseudoreplication ${ }^{89-94}$. GraphPad Prism version 8.0.1.244 for Windows (GraphPad Software, La Jolla, California, USA) was used for calculating descriptive statistics and plotting of diagrams. QGIS version $2.18 .24^{95}$ was used for drawing the study site map, shoot location schemes, and Kernel density analysis. 


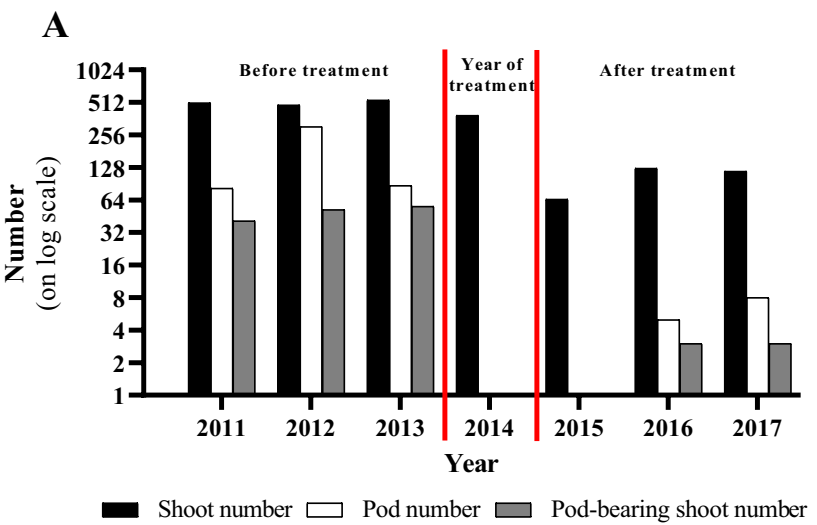

B

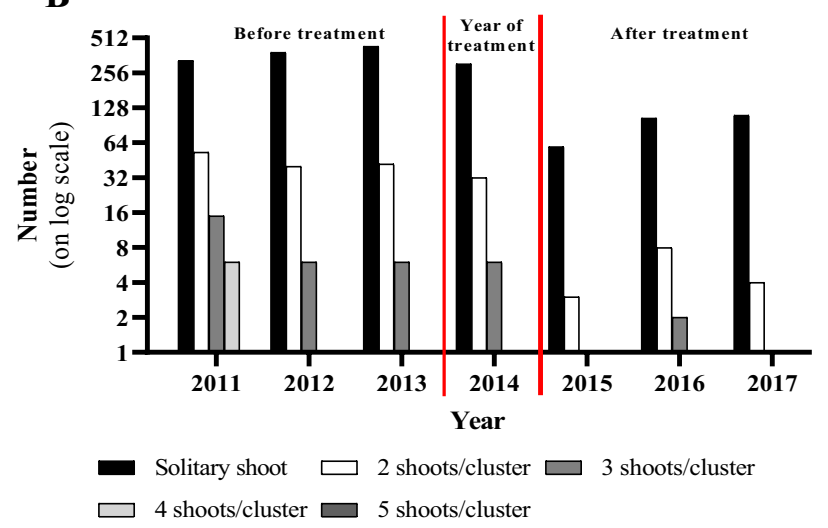

Figure 2. (A) Changes in the numbers of shoots, pod-bearing shoots, and pods (B) numbers of solitary and clustering milkweed shoots.

\section{Results}

A comparison of the before, treatment year and after treatment of the stand clearly shows differences in the heterogeneity and spatial intensity of the shoots.

Before herbicide treatment, we examined the stand composition from 2011 till 2013 (Figs. 2, 3). This period had the highest shoot number (about 500 shoots) with small fluctuations. In 2012, there was a smaller decrease in the shoot number (22) compared to that in 2011. In the next year (2013), the shoot number increased to 536. The number of solitary shoots increased, whereas that of the more common shoot clusters ( 2 and 3 shoots/cluster) decreased in the stand. The pod number showed some annual fluctuations in this period with the highest pod numbers ( 305 pods) in 2012. The annual difference in the number of pod-bearing shoots was small, it increased slightly over the years. The largest increase in the pod-bearing shoot number was in 2012 compared to 2011, but the most pod-bearing shoots (56) emerged in 2013. And it increased by 4 pieces in 2013.

In the year of herbicide treatment (2014), 388 shoots developed, but only 102 of them survived the treatment, but the pod production completely ceased. Due to the effects of the herbicide, $74 \%$ of the shoots died, although intact shoots were still observed in almost all areas of the stand (Figs. 2, 3). Solitary shoots were the predominant pattern in the stand (Figs. 2, 3).

After herbicide treatment, we examined the stand composition from 2015 till 2017. While the number of shoots and pods temporarily decreased in the first year after treatment, an increase was observed over the longerterm. A further decrease was observed in the number of shoots in 2015, with almost half of the shoots that have survived from the previous year dying (from 102 survived shoots to 65; Figs. 2, 3). An increase in the number of new shoots and pods was observed from the second year after treatment, although it did not reach its original densities (Fig. 3). The number of solitary shoots increased moderately, whereas the number of those with two or three shoots/cluster decreased after treatment (Fig. 2). The proportion of solitary shoots never decreased below $60 \%$. The solitary shoots represented a higher proportion than in the first period: in 2015, the proportion of the solitary shoots was $90.76 \%$. In 2016 , it was $82.53 \%$ and in 2017 , it was $93.22 \%$. The number of pod-bearing shoots was low: in 2015, there were not pod-bearing shoots, while there were three in 2016 and 2017.

The density of the shoots changed after the treatment; the former dense milkweed stand almost disappeared by glyphosate treatment in 2014, whereas the size of the occupied area by the stand remained almost unchanged, as all the parts remained occupied after treatment (Figs. 2, 3). It is important to note that before and in the year of herbicide application, all the solitary shoots and shoot clusters were recognized forming an extensive and strongly connected, dense stand with one focus point. Compared to the center, the density was lower at the edges of the stand (Fig. 3). After the herbicide treatment, the stand had a lower density of shoots, the shoot clusters vanished, 


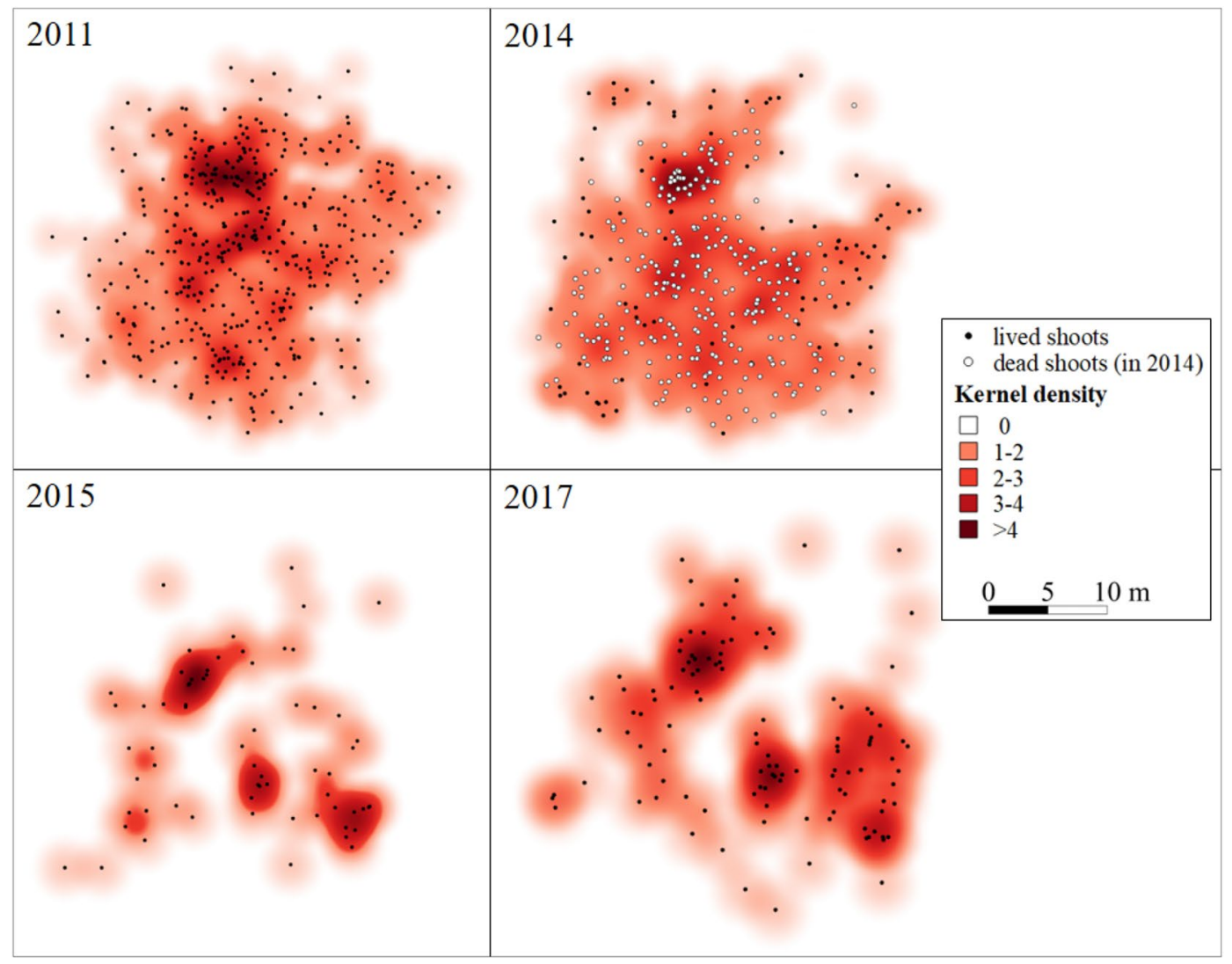

Figure 3. Kernel density of the stand illustrate the arrangement and extension of shoot density changes on the test surface in time: before herbicide treatment (in 2011), the treatment year (2014), and during two years after herbicide treatment (in 2015 and 2017).

and the stand was fragmented into three smaller isolated foci. The density of these three parts increased after herbicide treatment with sparser edges (Fig. 3).

\section{Discussion}

Our aims were to demonstrate the effects of a single herbicide treatment on the invasive clonal common milkweed. The herbicide treatment influenced the further spread and the trade-off between sexual reproduction and clonal propagation of the invasive common milkweed. There were huge shoot number differences between before and after the herbicide treatment period. Herbicide treatment caused a strong decrease in shoot numbers in the year of the treatment and in the first year after treatment. There are some studies that mechanical control causes a stronger resprouting in A. syriaca stands in contrast to our results. One study has reported that one-time cultivation (as a mechanical control) has no effects on milkweed abundance in arable lands ${ }^{79}$. A two years-long study reported that common milkweed shoots resprouted strongly after mechanical control ${ }^{80}$. In the case of the clonal woody Ailanthus altissima, Badalamenti et al. ${ }^{16}$ found that more shoots were sprouted after cutting than with combined treatment (herbicide application and cutting). The most likely explanation for this is that dormant bud banks become active in the absence of apical dominance. In accordance with our study, herbicide treatment (even one-time application) is undoubtedly more effective than cultivation or cutting, as reported by Zalai et al. ${ }^{80}$ wherein damage from glyphosate reduced the shoot numbers in the second season (resprouting in their study was half of that in the previous year). Similarly, the resprouted shoots of C. arvense were weaker and less dense in the year following herbicide treatment or mechanical control ${ }^{37}$. Moreover, Doğramacı et al.$^{96}$ showed that foliar glyphosate treatment reduced the vegetative growth of Euphorbia esula and altered hormone synthesis in crown buds. Saunders and Pezeshki $\mathrm{i}^{53}$ suggested that changes in leaf and shoot production in Ludwigia peploides after herbicide treatment can be a result of translocation-induced hormesis effect. As it was observed in C. arvense, glyphosate can translocate across the root toward root buds ${ }^{97-99}$, presumably similar mechanism can occur in the case of A. syriaca, because of the similar root system architecture ${ }^{37,100,101}$. When Savini et al..$^{52}$ applied glyphosate to Fragaria chiloensis shoots, they found that it was translocated from treated to untreated shoots in the same clone, causing death in both of them. This type of translocation was observed in our study in the year and after the first year of herbicide treatment (2014 and 2015). Therefore, the reduced number of milkweed shoots in this period could be a result of translocated herbicide by rhizomatic roots which could damage dormant bud banks.

The effects of herbicide treatment on reproductive characters (pod and pod-bearing shoots) have been rarely monitored in clonal plants. These reproductive characters play an important role in the spread as well as informs 
about viability. As a result of herbicide treatment, the pods disappeared in the year of the treatment and the first year after treatment and then they began to recover (Fig. 2). From this data, it can be concluded that sexual reproduction was delayed in the two years after herbicide treatment and only began to increase thereafter, indicating that the stand allocated its resources in favor of clonal growth for survival. This is consistent with numerous observations that sexual reproduction is of secondary importance in clonal plant ${ }^{102-104}$. However, herbicide treatment did not alter the proportions of shoot clusters compared to those before treatment (Fig. 2). It can be concluded that the stand regained its vitality and a one-time herbicide application was not effective to reduce seed production in the longer term. Earlier, Guo et al. ${ }^{14}$ came to a similar conclusion after studying seed production of herbicide treated Solidago canadensis. Based on these results, the herbicide treatment could be effective if repeated within the following two years to exterminate invasive clonal plants.

In order to reveal the alterations density and regrowth, Kernel density was used. The Kernel density of the milkweed stand strongly decreased and the stand became fragmented forming three hotspots with shoot clusters due to the single herbicide treatment (Fig. 3). Clonal plants show two main growth forms: phalanx growth form associated with space-occupancy strategy while the guerrilla is a foraging strategy ${ }^{105}$. However, the combined use of these two growth forms has already been shown in many species ${ }^{35,106,107}$. A. syriaca has a flexible clonal structure, the plant is able to use denser shoot structure (phalanx type) in favourable habitats and sparser once (guerrilla type) in less suitable habitats ${ }^{69}$. But in this study, the stand did not show any growth in the year of treatment (2014). The guerrilla growth type was typical in 2015 (Fig. 3), showing that this type may serve survival after disturbance. In the next years (in 2016 and 2017), fragments of the stand began to use both growth types again. Our results show that $A$. syriaca used both growth forms (phalanx and guerrilla) for the recovery. The plant is able to use a denser shoot structure for maintaining the formerly occupied area and sparser shoot structure for the colonization of new areas. It seems that the three fragments created new hotspots showing the high spreading potential of the species. It can be concluded that repeated herbicide treatment can be a strategy to prevent milkweed spread.

Based on these results we could determine that one single herbicide treatment of $A$. syriaca stand resulted in severe shoot loss but many shoots could survive indicating that the single treatment was a successful control measure in short but not in the longer-term. Successful survival can be attributed to vegetative propagation, which produces adventitious shoot buds on rhizomatic roots ${ }^{69,76}$ creating a large dormant bud bank. Based on the study of Schmid ${ }^{108}$, the activation of the bud bank in the case of other species depends on clone conditions. This dependence was observed in the case of $A$. syriaca, as several buds appeared on their rhizomatic roots. However, only one or a few of them are activated, whereas the others remain dormant in a given year ${ }^{109}$. The large number of solitary milkweed shoots in the clonal structure shows that the species applies density-dependent regulation to reduce or avoid intraclonal competition. In addition, the shoots will be either vegetative or pod-bearing ${ }^{110}$ as the reproductive output (pod and seed production) is resource limited based on the study of three milkweed species (including A. syriaca) $)^{111}$. The drastically reduced pod numbers indicate that the pod number as a reproductive output can be a useful indicator for predicting or monitoring the vitality of clonal plants. Successful regrowth of A. syriaca benefits greatly from its clonal characteristics and growth after treatment. An extensive dormant bud bank may be activated by disturbance ${ }^{55,60}$. Waldecker and Wyse ${ }^{112}$ found that buds of A. syriaca in the proximal part of the rhizomatic root system accumulated less radioactively labeled glyphosate than distal root buds. Therefore, proximal rhizomatic root buds are more dormant than distal ones and thus accumulate less glyphosate. The surviving and newly propagated buds on rhizomatic roots adjusted the numbers of emerging shoots in the years after treatment, and reconstruction of dormant bud banks in 2015 explains the spatial position of the shoots during that period. Our mid-term study demonstrated that a single application of herbicide is successful in the short but not enough on the longer term. The shoot number showed an increase over the longer-term but, the recovery of original shoot numbers in a milkweed stand takes a longer time. The complete destruction of a clone can only be accomplished by methods that affect the entire system of the bud bank and shoots because the mortality risk is distributed among the interconnected bud bank and shoots in a clone ${ }^{40,56-62}$. This indicates that rhizomatous roots and bud banks can create a successful and persistent colonization system, thus making periodic control more effective than a one-time treatment. Thus, in spite of that single herbicide treatment is really suitable for density control in short-term ${ }^{80}$, but it seems the growth of common milkweed stand shows a slow regeneration for a longer-term period.

Furthermore, herbicide treatment raises further questions concerning the native vegetation, especially in nature reserves. We did not observe any visible changes in the vegetation in the year of the treatment and the years after treatment. In contrast to this study, some short-term studies showed that the non-target vegetation was degraded by herbicide application. For example, Gibbson et al. ${ }^{19}$ showed that the phylogenetic diversity of the community became lower due to single herbicide treatment. Szitár and Törö $\mathrm{k}^{20}$ also showed that the single herbicide spraying of common milkweed disturbed the vegetation, and it modified the succession to an earlier initial state. One possible explanation for the absence of non-target side effect is that manual lubrication was applied in the present study, which resulted in a more selective and efficient control method than spraying. These multiple goals require complex and long-term investigations (e.g. pre-invasion conditions are also taken into account).

\section{Conclusions}

In recent years control of invasive species receives a special attention in order to protect natural habitats. The current research surveyed the effect of a single herbicide treatment on one isolated A. syriaca stand located in open sand grassland of a protected area. Results of the very fine and temporal replicated sampling method demonstrated that single herbicide treatment modified not just the reproductive output of these invasive species but also their vegetative growth. The clones altered the resource allocation between reproduction and clonal growth in order to survive the herbicide application. The stand became fragmented after the herbicide application 
generating new hotspots for further clonal spread. Our mid-term case study showed that a large milkweed stand not only can survive a single herbicide treatment but regain its vitality in function of time. Therefore, the first and the second year after herbicide treatment could be optimal period for successful application of further herbicide treatment. The findings of the present study confirm that monitoring of invasive plant control is recommended to be continued for several years after herbicide treatment, especially in the case of clonal plants. Furthermore, long-term examination of the natural vegetation can also broaden our knowledge to clarify how herbicide applications modify natural community. Due to herbicide treatment diminished number of invasive plants might influence the recovery of native species. These results can be useful for plant management of invasive clonal plants or other type of herbicides in the future.

\section{Data availability}

Data will be available where applicable.

Received: 10 February 2020; Accepted: 10 August 2020

Published online: 26 August 2020

\section{References}

1. Kettunen, M. et al. Technical support to EU strategy on invasive alien species (IAS)-Assesment of the impacts of IAS in Europe and EU. (Institute for European Environmental Policy (IEEP), 2009).

2. Keller, R. P., Geist, J., Jeschke, J. M. \& Kühn, I. Invasive species in Europe: ecology, status, and policy. Environ. Sci. Europe 23, 23. https://doi.org/10.1186/2190-4715-23-23 (2011).

3. European Commission. Regulation No 1143/2014 of the European Parliament and of the Council October 222014 on the prevention and management of the introduction and spread of invasive alien species. Off. J. Eur. Union. L174, 5-11; https://publi cations.europa.eu/en/publication-detail//publication/880597b7-63f6-11e4-9cbe-01aa75ed71a1/lan-guage-en (2014).

4. Olden, J. D., Comte, L. \& Giam, X. The Homogocene: a research prospectus for the study of biotic homogenisation. NeoBiota 37, 23. https://doi.org/10.3897/neobiota.37.22552 (2018).

5. Scalera, R. How much is Europe spending on invasive alien species?. Biol. Invas. 12, 173-177. https://doi.org/10.1007/s1053 0-009-9440-5 (2010)

6. European Commission. Proposal for a regulation of the European parliament and of the council on the prevention and management of the introduction and spread of invasive alien species. https://eur-lex.europa.eu/legal-content/EN/TXT/?uri=CELEX \%3A52013PC0620 (2013).

7. International Union for Conservation of Nature (IUCN). Compilation of costs of prevention and management of invasive alien species in the EU. Technical note prepared by IUCN for the European Commission. https://circabc.europa.eu/sd/a/7b04a 898-12e3-48c3-a0e5-f2 1a165259b4/2018-Compilation\%20of\%20 costs\%20of\%20prevention\%20and\%20management $\% 20$ of $\% 20$ IAS\%20in\%20the\%20EU.pdf (2018).

8. Zamora, D. L., Thill, D. C. \& Eplee, R. E. An eradication plan for plant invasions. Weed. Technol. 3, 2-12. https://doi.org/10.1017/ S0890037X00031225 (1989)

9. Caffrey, J. M. et al. Tackling invasive alien species in Europe: the top 20 issues. Manag. Biol. Invas. 5, 1-20. https://doi.org/10.3391/ mbi.2014.5.1.01 (2014).

10. Csiszár, Á. \& Korda, M. In Practical experiences in invasive alien plant control (ed Csiszár, Á. \& Korda, M.) 203-235 (Duna-Ipoly Nemzeti Park Igazgatóság, 2015).

11. Shannon, C., Quinn, C. H., Stebbing, P. D., Hassall, C. \& Dunn, A. M. The practical application of hot water to reduce the introduction and spread of aquatic invasive alien species. Manag. Biol. Invas. 9, 417-423. https://doi.org/10.3391/mbi.2018.9.4.05 (2018).

12. Mauvisseau, Q. et al. detection of an emerging invasive species: eDNA monitoring of a parthenogenetic crayfish in freshwater systems. Manag. Biol. Invas. 10, 461-472. https://doi.org/10.3391/mbi.2019.10.3.04 (2019).

13. Sepulveda, A., Amberg, J. \& Hanson, E. Using environmental DNA to extend the window of early detection for dreissenid mussels. Manag. Biol. Invas. 10, 342-358. https://doi.org/10.3391/mbi.2019.10.2.09 (2019).

14. Guo, S. L., Jiang, H. W., Fang, F. \& Chen, G. Q. Influences of herbicides, uprooting and use as cut flowers on sexual reproduction of Solidago canadensis. Weed Res. 49, 291-299. https://doi.org/10.1111/j.1365-3180.2009.00693.x (2009).

15. Rudenko, M. \& Hulting, A. Integration of chemical control with restoration techniques for management of Fallopia japonica populations. Manag. Biol. Invas. 1, 37-49 (2010).

16. Badalamenti, E., Barone, E. \& La Mantia, T. Seasonal effects on mortality rates and resprouting of stems treated with glyphosate in the invasive tree of heaven (Ailanthus altissima (Mill.) Swingle). Arboricult. J. 37, 180-195. https://doi.org/10.1080/03071 375.2015.1112163 (2015).

17. Boyd, N. S., White, S. N. \& Larsen, T. Sequential aminopyralid and imazapyr applications for Japanese knotweed (Fallopia japonica) management. Invasive. Plant. Sci. Manag. 10, 277-283. https://doi.org/10.1017/inp.2017.31 (2017).

18. Caudill, J. et al. Aquatic plant community restoration following the long-term management of invasive Egeria densa with fluridone treatments. Manag. Biol. Invas. 10, 473-485. https://doi.org/10.3391/mbi.2019.10.3.05 (2019).

19. Gibson, D. J., Shupert, L. A. \& Liu, X. Do no harm: efficacy of a single herbicide application to control an invasive shrub while minimizing collateral damage to native species. Plants 8, 426. https://doi.org/10.3390/plants8100426 (2019).

20. Szitár, K. \& Török, K. Short-term effects of herbicide treatment on the vegetation of semiarid sandy oldfields invaded by Asclepias syriaca L. Extended abstract in the Proceedings of the 6th European Conference on Ecological Restoration, 9, 8-12 (2008).

21. Stark, J. D., Chen, X. D. \& Johnson, C. S. Effects of herbicides on Behr's metalmark butterfly, a surrogate species for the endangered butterfly, Lange's metalmark. Environ. Pollut. 164, 24-27. https://doi.org/10.1016/j.envpol.2012.01.011 (2012).

22. Commission, E. Regulation No 1107/2009 of the European Parliament and of the Council of 21 October 2009 concerning the placing of plant protection products on the market and repealing Council Directives 79/117/EEC and 91/414/EEC. Off. J. Eur. Union. 50, 1-50 (2009).

23. Working Group on Invasive Alien Species. Management of Invasive Alien Species of Union Concern. https://circabc.europa.eu/ faces/jsp/extension/wai/navigation/container.jsp (2017).

24. Pyšek, P. In The Ecology and Evolution of Clonal Plants (ed de Kroon, H. \& van Groenendael, J.) 405-427 (Backhuys Publishers, 1997).

25. Pyšek, P. \& Richardson, D. M. In Biological invasions (ed Nentwig, W.) 97-126 (Springer, Berlin 2007)

26. Speek, T. A. et al. Factors relating to regional and local success of exotic plant species in their new range. Divers. Distrib. 17, 542-551. https://doi.org/10.1111/j.1472-4642.2011.00759.x (2011). 
27. Douhovnikoff, V. \& Hazelton, E. L. Clonal growth: invasion or stability? A comparative study of clonal architecture and diversity in native and introduced lineages of Phragmites australis (Poaceae). Am. J. Bot. 101, 1577-1584. https://doi.org/10.3732/ajb.14001 77 (2014).

28. Wang, N. et al. Clonal integration affects growth, photosynthetic efficiency and biomass allocation, but not the competitive ability, of the alien invasive Alternanthera philoxeroides under severe stress. Ann. Bot. 101, 671-678. https://doi.org/10.1093/ $\mathrm{aob} / \mathrm{mcn} 005$ (2008)

29. Xu, L. \& Zhou, Z. F. Effects of Cu pollution on the expansion of an amphibious clonal herb in aquatic-terrestrial ecotones. PLoS ONE 11, e0164361. https://doi.org/10.1371/journal.pone.0164361 (2016).

30. You, W.-H. et al. Effects of clonal integration on the invasive clonal plant Alternanthera philoxeroides under heterogeneous and homogeneous water availability. Sci. Rep. 6, 29767. https://doi.org/10.1038/srep29767 (2016).

31. Smith, J. M. D., Ward, J. P., Child, L. E. \& Owen, M. R. A simulation model of rhizome networks for Fallopia japonica (Japanese knotweed) in the United Kingdom. Ecol. Model. 200, 421-432. https://doi.org/10.1016/j.ecolmodel.2006.08.004 (2007).

32. Balogh, L. In The most important invasive plants in Hungary. (ed Botta Dukát, Z., Balogh, L.) 13-33 (Institute of Ecology and Botany HAS, 2008).

33. Padula, M. et al. Prime segnalazioni di Reynoutria $\times$ bohemica Chrtek and Chrtková (Polygonaceae) per l'Italia e analisi della distribuzione del genere Reynoutria Houtt. Atti. Soc. It. Sci. Nat. Museo Civ. Stor. Nat. Milano. 149, 77-108 (2008) (in Italian)

34. Jones, D. et al. Optimising physiochemical control of invasive Japanese knotweed. Biol. Invasions. 20, 2091-2105. https://doi. org/10.1007/s10530-018-1684-5 (2018)

35. Martin, F. M., Dommanget, F., Lavallée, F. \& Evette, A. Clonal growth strategies of Reynoutria japonica in response to light, shade, and mowing, and perspectives for management. NeoBiota 56, 89-110. https://doi.org/10.3897/neobiota.56.47511 (2020).

36. Szymura, M. \& Szymura, T. H. Growth, phenology, and biomass allocation of alien Solidago species in central Europe. Plant. Spec. Biol. 30, 245-256. https://doi.org/10.1111/1442-1984.12059 (2015).

37. Tiley, G. E. D. Biological Flora of the British Isles: Cirsium arvense (L.) Scop. J. Ecol. 98, 938-983. https://doi.org/10.111 1/j.1365-2745.2010.01678.x (2010)

38. Nentwig, W. \& Müller, E. Plant pathogens as biocontrol agents of Cirsium arvense-an overestimated approach?. NeoBiota 11, 1-24. https://doi.org/10.3897/neobiota.11.1803 (2011).

39. Alpert, P. Nitrogen sharing among ramets increases clonal growth in Fragaria chiloensis. Ecology 72, 69-80. https://doi. org/10.2307/1938903 (1991).

40. Oborny, B. \& Bartha, S. Clonality in plant communities-an overview. Abstr. Bot. 19, 115-127 (1995).

41. de Kroon, H., van der Zalm, E., van Rheenen, J. W., van Dijk, A. \& Kreulen, R. The interaction between water and nitrogen translocation in a rhizomatous sedge (Carex flacca). Oecologia 116, 38-49. https://doi.org/10.1007/s004420050561 (1998).

42. de Kroon, H. \& van Groenendael, J. The ecology and evolution of clonal plants. (Backhuys Publishers, London 1997).

43. Zhang, Y. C., Zhang, Q. Y., Yirdaw, E., Luo, P. \& Wu, N. Clonal integration of Fragaria orientalis driven by contrasting water availability between adjacent patches. Bot. Stud. 49, 373-383 (2008)

44. Wang, Y. J. et al. Invasive alien plants benefit more from clonal integration in heterogeneous environments than natives. New Phytol. 216, 1072-1078. https://doi.org/10.1111/nph.14820 (2017).

45. Frantzen, J. The role of clonal growth in the pathosystem Cirsium arvense-Puccinia punctiformis. Can. J. Bot. 72, 832-836. https ://doi.org/10.1139/b94-107 (1994)

46. D'hertefeldt, T. \& van der Putten, W. Physiological integration of the clonal plant Carex arenaria and its response to soil-borne pathogens. Oikos 81, 229-237. https://doi.org/10.2307/3547044 (1998).

47. Stuefer, J. F., Gómez, S. \& van Mölken, T. Clonal integration beyond resource sharing: implications for defense signaling and disease transmission in clonal plant networks. Evol. Ecol. 18, 647-667. https://doi.org/10.1007/s10682-004-5148-2 (2004).

48. Bankó, L., Ördög, M. \& Erdei, L. The role of rhizome system in the distribution of cadmium load among ramets of Phragmites australis. Acta. Biol. Szeged. 46, 81-82 (2002).

49. Xu, L., Wu, X. \& Zhou, Z. F. Effects of physiological integration and fertilization on heavy metal remediation in soil by a clonal grass. Pol. J. Environ. Stud. 25, 1, https://doi.org/10.15244/pjoes/60374 (2016).

50. Chang, F. Y. \& Born, W. V. Translocation of dicamba in Canada thistle. Weed Sci. 16, 176-181. https://doi.org/10.1017/S0043 174500046841 (1968).

51. Wyrill, I. I. I. J. B. \& Burnside, O. C. Absorption, translocation, and metabolism of 2,4 D and glyphosate in common milkweed and hemp dogbane. Weed Sci. 24, 557-566, https://doi.org/10.1017/S0043174500062949 (1976).

52. Savini, G., Giorgi, V., Scarano, E. \& Neri, D. Strawberry plant relationship through the stolon. Physiol. Plant. 134, 421-429. https ://doi.org/10.1111/j.1399-3054.2008.01145.x (2008).

53. Saunders, L. E. \& Pezeshki, R. Morphological differences in response to physiological integration and spatial heterogeneity of root zone glyphosate exposure in connected ramets of Ludwigia peploides (Creeping water primrose). Water Air Soil Pollut. 226, 171. https://doi.org/10.1007/s11270-015-2435-1 (2015).

54. Klimešová, J. \& Herben, T. Clonal and bud bank traits: patterns across temperate plant communities. J. Veg. Sci. 26, $243-253$. https://doi.org/10.1111/jvs.12228 (2015).

55. Klimešová, J., Martínková, J. \& Herben, T. Horizontal growth: an overlooked dimension in plant trait space. Perspect. Plant Ecol. 32, 18-21. https://doi.org/10.1016/j.ppees.2018.02.002 (2018).

56. Inghe, O. Genet and ramet survivorship under different mortality regimes-a cellular automata model. J. Theor. Biol. 138, 257-270. https://doi.org/10.1016/S0022-5193(89)80142-0 (1989).

57. Tuomi, J. \& Vuorisalo, T. Hierarchical selection in modular organisms. Trends Ecol. Evol. 4, 209-213. https://doi.org/10.1016/01695347(89)90075-X (1989)

58. Eriksson, O. \& Jerling, L. In Clonal growth in plants: regulation and function (ed van Groenendael, J. \& de Kroon, H.) 79-94 (SPB Academic Publishing, 1990).

59. Watkinson, A. R. \& Powell, J. C. Seedling recruitment and the maintenance of clonal diversity in plant populations-a computer simulation of Ranunculus repens. J. Ecol. 81, 707-717 (1993).

60. Newton, P. C. D. \& Hay, M. J. M. Non-viability of axillary buds as a possible constraint on effective foraging of Trifolium repens L. Abstr. Bot. 19, 83-88 (1995)

61. Latzel, V., Mihulka, S. \& Klimešová, J. Plant traits and regeneration of urban plant communities after disturbance: Does the bud bank play any role?. Appl. Veg. Sci. 11, 387-394. https://doi.org/10.3170/2008-7-18487 (2008).

62. Scherrer, D., Stoll, P. \& Stöcklin, J. Colonization dynamics of a clonal pioneer plant on a glacier foreland inferred from spatially explicit and size-structured matrix models. Folia Geobot. 52, 1-14. https://doi.org/10.1007/s12224-017-9294-z (2017).

63. Schiffleithner, V. \& Essl, F. It is worth the effort? Spread and management success of invasive alien plant species in a Central European National Park. NeoBiota 31, 43-61. https://doi.org/10.3897/neobiota.31.8071 (2016).

64. Blossey, B. Before, during and after: the need for long-term monitoring in invasive plant species management. Biol. Invas. 1, 301-311. https://doi.org/10.1023/A:1010084724526 (1999).

65. Kettenring, K. M. \& Adams, C. R. Lessons learned from invasive plant control experiments: a systematic review and metaanalysis. J. Appl. Ecol. 48, 970-979. https://doi.org/10.1111/j.1365-2664.2011.01979.x (2011).

66. Delbart, E. et al. Can land managers control Japanese knotweed? Lessons from control tests in Belgium. Environ. Manag. 50, 1089-1097. https://doi.org/10.1007/s00267-012-9945-z (2012). 
67. Clements, D., Dugdale, T. M., Butler, K. L. \& Hunt, T. D. Management of aquatic alligator weed (Alternanthera philoxeroides) in an early stage of invasion. Manage. Biol. Invas. 5, 327-339. https://doi.org/10.3391/mbi.2014.5.4.03 (2014).

68. Tokarska-Guzik, B. \& Pisarczyk, E. Risk Assessment of Asclepias syriaca. https://www.codeplantesenvahissantes.fr/fileadmin/ PEE_Ressources/TELECHARGEMENT/Asclepias_syriaca_RA.pdf (2015).

69. Bagi, I. In The most important invasive plants in Hungary. (ed Botta-Dukát, Z., Balogh, L.) 151-159 (Institute of Ecology and Botany HAS, 2008).

70. Commonwealth Agricultural Bureau International (CABI). Asclepias syriaca (common milkweed). https://www.cabi.org/isc/ datasheet/7249 (2011)

71. European Invasive Alien Species Gateway (DAISIE). https://www.europe-aliens.org/speciesFactsheet.do?speciesId=17716\# (2015).

72. Szilassi, P. et al. Understanding the environmental background of an invasive plant species (Asclepias syriaca) for the future: an application of LUCAS field photographs and machine learning algorithm methods. Plants 8, 593. https://doi.org/10.3390/plant s8120593 (2019).

73. Kelemen, A. et al. The invasion of common milkweed (Asclepias syriaca) in sandy old-fields-is it a threat to the native flora?. Appl. Veg. Sci. 19, 218-224. https://doi.org/10.1111/avsc.12225 (2016).

74. Bakacsy, L. Invasion impact is conditioned by initial vegetation states. Commun. Ecol. 20, 11-19. https://doi. org/10.1556/168.2019.20.1.2 (2019).

75. European Commissions. List of Invasive Alien Species of Union concern. https://ec.europa.eu/environment/nature/invasiveal ien/list/index_en.htm (2017).

76. Wilbur, H. M. Life history evolution in seven milkweeds of the genus Asclepias. J. Ecol. 64, 223-240 (1976).

77. Pellissier, L. et al. Different rates of defense evolution and niche preferences in clonal and nonclonal milkweeds (Asclepias spp.). New Phytol. 209, 1230-1239, https://doi.org/10.1111/nph.13649 (2016).

78. Balogh, Á., Penksza, K. \& Benécsné, B. G. Kísérletek a selyemkóróval fertőzött természetközeli gyepek mentesítésére I. (Experiments for immunization of Asclepias syriaca infected turfs) Tájökológiai lapok 4, 385-394 (2006).

79. Papka, O. S. Agro-ecological effectivness of soil technologies as controling tool for common wilkweed (Asclepias syriaca L.). Acta Biolol. Sibirica 1, 244-257 (2015).

80. Zalai, M. et al. Developing control strategies against common milkweed (Asclepias syriaca L.) on ruderal habitats. Herbologia 16, 69-84, https://doi.org/10.5644/Herb.16.2.07 (2017).

81. Bolla, B. Invasive control at Csengödi Plain. Természetvédelmi Közlemények 18, 77-81 (2012).

82. Molnár, Z. \& Kun, A. Magyarország élőhelyei: vegetációtipusok leirása és határozója: ÁNÉR 2011. (MTA Ökológiai és Botanikai Kutatóintézete, 2011).

83. Zsákovics, G., Kovács, F., Kiss, A. \& Pócsik, E. Risk analysis of the aridification-endangered sand-ridge area in the Danube-Tisza Interfluve. Acta Climatol. Chorol. Univ. Szeged 40, 169-178 (2007).

84. Zsákovics, G., Kovács, F. \& Kiss, A. Complex analysis of an aridification-endangered area: case study from the Danube-Tisza Interfluve. Tájökológiai Lapok 7, 117-126 (2009).

85. Kovács-Láng, E. et al. Changes in the composition of sand grasslands along a climatic gradient in Hungary and implications for climate change. Phytocoenologia 30, 385-407. https://doi.org/10.1127/phyto/30/2000/385 (2000).

86. Kun, A. Analysis of precipitation year and their regional frequency distributions in the Danube-Tisza mid-region, Hungary . Acta. Bot. Hung. 43, 175-187. https://doi.org/10.1556/ABot.43.2001.1-2.10 (2001).

87. Bartha, S. et al. Beta diversity and community differentiation in dry perennial sand grassland. Ann. Bot. 9-18, 2011. https://doi. org/10.4462/annbotrm-9118 (2011).

88. Mihály, B. \& Botta-Dukát, Z. Biológiai inváziók Magyarországon: Özönnövények. (Biological invasions in Hungary: Invasive plants). (TermészetBÚVÁR Alapítvány Kiadó, 2004).

89. Hurlbert, S. H. Pseudoreplication and the design of ecological field experiments. Ecol. Monogr. 54, 187-211. https://doi. org/10.2307/1942661 (1984).

90. Oksanen, L. Logic of experiments in ecology: is pseudoreplication a pseudoissue?. Oikos 94, 27-38. https://doi.org/10.103 4/j.1600-0706.2001.11311.x (2001).

91. Davies, G. M. \& Gray, A. Don't let spurious accusations of pseudoreplication limit our ability to learn from natural experiments (and other messy kinds of ecological monitoring). Ecol. Evol. 5, 5295-5304. https://doi.org/10.1002/ece3.1782 (2015).

92. Colegrave, N. \& Ruxton, G. D. Using biological insight and pragmatism when thinking about pseudoreplication. Trends. Ecol. Evol. 33, 28-35. https://doi.org/10.1016/j.tree.2017.10.007 (2018).

93. Jordan, C. Y. Population sampling affects pseudoreplication. PLoS Biol. 16, e2007054. https://doi.org/10.1371/journal.pbio.20070 54 (2018).

94. Gratton, P. \& Mundry, R. Accounting for pseudoreplication is not possible when the source of nonindependence is unknown. Anim. Behav. 154, e1-e5. https://doi.org/10.1016/j.anbehav.2019.05.014 (2019).

95. QGIS Development Team. QGIS Geographic Information System. Open Source Geospatial Foundation Project. https://qgis.osgeo .org (2019).

96. Doğramaci, M., Anderson, J. V., Chao, W. S. \& Foley, M. E. Foliar application of glyphosate affects molecular mechanisms in underground adventitious buds of leafy spurge (Euphorbia esula) and alters their vegetative growth patterns. Weed Sci. 62, 217-229. https://doi.org/10.1614/WS-D-13-00156.1 (2014).

97. McAllister, R. S. \& Haderlie, L. C. Translocation of ${ }^{14} \mathrm{C}$-glyphosate and ${ }^{14} \mathrm{CO}$ 2-labeled photoassimilates in Canada thistle (Cirsium arvense). Weed Sci. 33, 153-159. https://doi.org/10.1017/S0043174500082011 (1985).

98. Carlson, S. J. \& Donald, W. W. Glyphosate effects on Canada thistle (Cirsium arvense) roots, root buds, and shoots. Weed Res. 28, 37-45. https://doi.org/10.1111/j.1365-3180.1988.tb00783.x (1988).

99. Hunter, J. H. Effect of bud vs rosette growth stage on translocation of ${ }^{14} \mathrm{C}$-glyphosate in Canada thistle (Cirsium arvense). Weed Sci. 43, 347-351. https://doi.org/10.1017/S0043174500081303 (1995).

100. Polowick, P. L. \& Raju, M. V. S. The origin and development of root buds in Asclepias syriaca. Can. J. Bot. 60, 2119-2125. https ://doi.org/10.1139/b82-260 (1982).

101. Stamm-Katovich, E. J., Wyse, D. L. \& Biesboer, D. D. Development of common milkweed (Asclepias syriaca) root buds following emergence from lateral roots. Weed Sci. 36, 758-763. https://doi.org/10.1017/S0043174500075780 (1988).

102. Eckert, C.G. In Ecology and evolutionary biology of clonal plants (ed Stuefer J.F., Erschbamer B., Huber H., Suzuki J.-I.) $279-298$. (Springer, Dordrecht, 2002).

103. Barrett, S. C. Influences of clonality on plant sexual reproduction. Proc. Natl. Acad. Sci. USA 112, 8859-8866. https://doi. org/10.1073/pnas.1501712112 (2015).

104. Herben, T., Šerá, B. \& Klimešová, J. Clonal growth and sexual reproduction: tradeoffs and environmental constraints. Oikos 124, 469-476. https://doi.org/10.1111/oik.01692 (2015).

105. Doust, L. L. Population dynamics and local specialization in a clonal perennial (Ranunculus repens): I. The dynamics of ramets in contrasting habitats. J. Ecol. 69, 743-755. https://doi.org/10.2307/2259633 (1981).

106. Chen, X. S., Xie, Y. H., Deng, Z. M., Li, F. \& Hou, Z. Y. A change from phalanx to guerrilla growth form is an effective strategy to acclimate to sedimentation in a wetland sedge species Carex brevicuspis (Cyperaceae). Flora 206, 347-350. https://doi. org/10.1016/j.flora.2010.07.006 (2011). 
107. Ye, X. et al. Multiple adaptations to light and nutrient heterogeneity in the clonal plant Leymus secalinus with a combined growth form. Flora 213, 49-56. https://doi.org/10.1016/j.flora.2015.04.006 (2015).

108. Schmid, B. Some ecological and evolutionary consequences of modular organization and clonal growth in plants. Evol. Trend. Plant. 4, 25-34 (1990).

109. Hsiao, A. I. \& McIntyre, G. I. Evidence of competition for water as a factor in the mechanism of root-bud inhibition in milkweed (Asclepias syriaca). Can. J. Bot. 62, 379-384. https://doi.org/10.1139/b84-057 (1984).

110. Watson, M. A. In Clonal growth in plants: regulation and function (ed van Groenendael, J. \& de Kroon, H.) 43-56 (SPB Academic Publishing, London 1990).

111. Willson, M. F. \& Price, P. W. Resource limitation of fruit and seed production in some Asclepias species. Can. J. Bot. 58, 2229-2233. https://doi.org/10.1139/b80-257 (1980).

112. Waldecker, M. A. \& Wyse, D. L. Soil moisture effects on glyphosate absorption and translocation in common milkweed (Asclepias syriaca). Weed Sci. 33, 299-305. https://doi.org/10.1017/S0043174500082321 (1985).

\section{Acknowledgements}

We are grateful to Kiskunság National Park Directores for allowing us to conduct field studies in the protected area and providing the specifications of implementation technologies. We would like to express our special thanks to Erika Dóri (from Department of Plant Biology, University of Szeged) for her assistance with field work over the years. We special thank to Ágnes Szepesi for her scientific comments. Last but not least we would like to thank for corrections of valuable comments of the anonymous reviewers. This research was supported by University of Szeged Open Access Fund, Grant No. 4648, and partly by the Ministry of Human Capacities, Grant ID: NTP-NFTÖ-19-B-0208.

\section{Author contributions}

I.B. and L.B. conceived and designed the study. L.B. conducted the analysis and drafted the manuscript. Both authors read and approved the final manuscript.

\section{Competing interests}

The authors declare no competing interests.

\section{Additional information}

Correspondence and requests for materials should be addressed to L.B.

Reprints and permissions information is available at www.nature.com/reprints.

Publisher's note Springer Nature remains neutral with regard to jurisdictional claims in published maps and institutional affiliations.

Open Access This article is licensed under a Creative Commons Attribution 4.0 International License, which permits use, sharing, adaptation, distribution and reproduction in any medium or format, as long as you give appropriate credit to the original author(s) and the source, provide a link to the Creative Commons license, and indicate if changes were made. The images or other third party material in this article are included in the article's Creative Commons license, unless indicated otherwise in a credit line to the material. If material is not included in the article's Creative Commons license and your intended use is not permitted by statutory regulation or exceeds the permitted use, you will need to obtain permission directly from the copyright holder. To view a copy of this license, visit http://creativecommons.org/licenses/by/4.0/.

(c) The Author(s) 2020 